\title{
Biological enhancement of estuarine benthic community structure
}

\author{
R. Warren Flint ${ }^{1} \&$ Richard D. Kalke ${ }^{2}$ \\ ${ }^{1}$ Research Center, State University oi New York College, Oswego, New York 13126, USA \\ ${ }^{2}$ The University of Texas, Marine Science Institute, Port Aransas, Texas 78373, USA
}

\begin{abstract}
Benthos in south Texas estuaries are normally concentrated in the top 3 to $4 \mathrm{~cm}$ where the sediment is well-oxygenated and less compact. Where larger infauna such as enteropneusts, ophiuroids, or echiurans occur in the sediments bioturbation by these infauna oxygenates and redistributes normally uninhabitated deeper sediments. A natural disturbance to Corpus Christi Bay benthos by these larger infauna could increase density and expansion of infaunal populations into deeper regions of the sediments, as well as enhance colonization by new infaunal species. During a $3.5 \mathrm{yr}$ study of infaunal benthos there was a change in community structure associated with colonization of the soft-bottom habitat by the enteropneust Schizocardium n. sp. that resulted in a species composition atypical for a middle estuary habitat. After 2 yr the enteropneust population disappeared and the diverse and productive soft-bottom community regressed to pre-enteropneust characteristics. Increased aerobic sediments during enteropneust presence may have diminished predicted competition and encouraged development of a more diverse community than would have otherwise existed.
\end{abstract}

\section{INTRODUCTION}

Detection of patterns in community organization, the identification of dominant forces that underlie these patterns, and the more universal application of theories developed from these studies are often major goals in the study of an ecological community. Given the complexity of most ecological systems, however, the identification of causative mechanisms influencing community organization is extremely difficult. Observed community patterns may be the result of responses to spatial or temporal change in the environment (Woodin 1978, 1981), to competition (MacArthur \& Levins 1967, Woodin 1976), to predation (e.g. Paine 1969, Connell 1975, Paine 1980), to chance events, or to the product of 2 or more interacting processes (Lewin 1983). Natural disturbances have been observed to be important structuring mechanisms that can alter both the habitat and associated organisms in soft-bottom communities (Woodin 1978, Virnstein 1979, Thistle 1980, Zajac \& Whitlatch 1982, Creed \& Coull 1984). Although many of these disturbances are thought to have biological impact (Coull \& Palmer 1984) the actual nature of the impact is often not identified.

Corpus Christi Bay, one of 7 major estuaries along the Texas coast of the Gulf of Mexico (Fig. 1), is located in a semi-arid, subtropical climate and usually receives less than $70 \mathrm{~cm}$ of rainfall annually. The low rainfall and small fluvial flow into this estuary often result in extended periods of higher salinities, more similar to oceanic conditions. The estuary is shallow, generally less than $5 \mathrm{~m}$ deep, and the presence of winds on almost a daily basis results in a great deal of wave scour and resuspension of muds at the sediment surface. Climatological and physical characteristics are thought to greatly influence the biological communities of this estuary.

Estuarine benthic infaunal communities in these south Texas coastal Gulf of Mexico waters have been investigated extensively (e.g. Flint \& Younk 1983, Flint \& Kalke 1985) in an attempt to elucidate factors responsible for their community organizations. Although long-term environmental fluctuations (Flint 1985) and spatial heterogeneity in sediment characteristics (Flint \& Kalke 1985) have been shown to influence estuarine-wide community patterns, subtle biological factors are also thought to significantly affect community organization changes in these softbottom sediment habitats. We investigated for the occurrence of natural biological disturbances in the soft-bottom community of Corpus Christi Bay to determine how widespread these disturbances were and to 


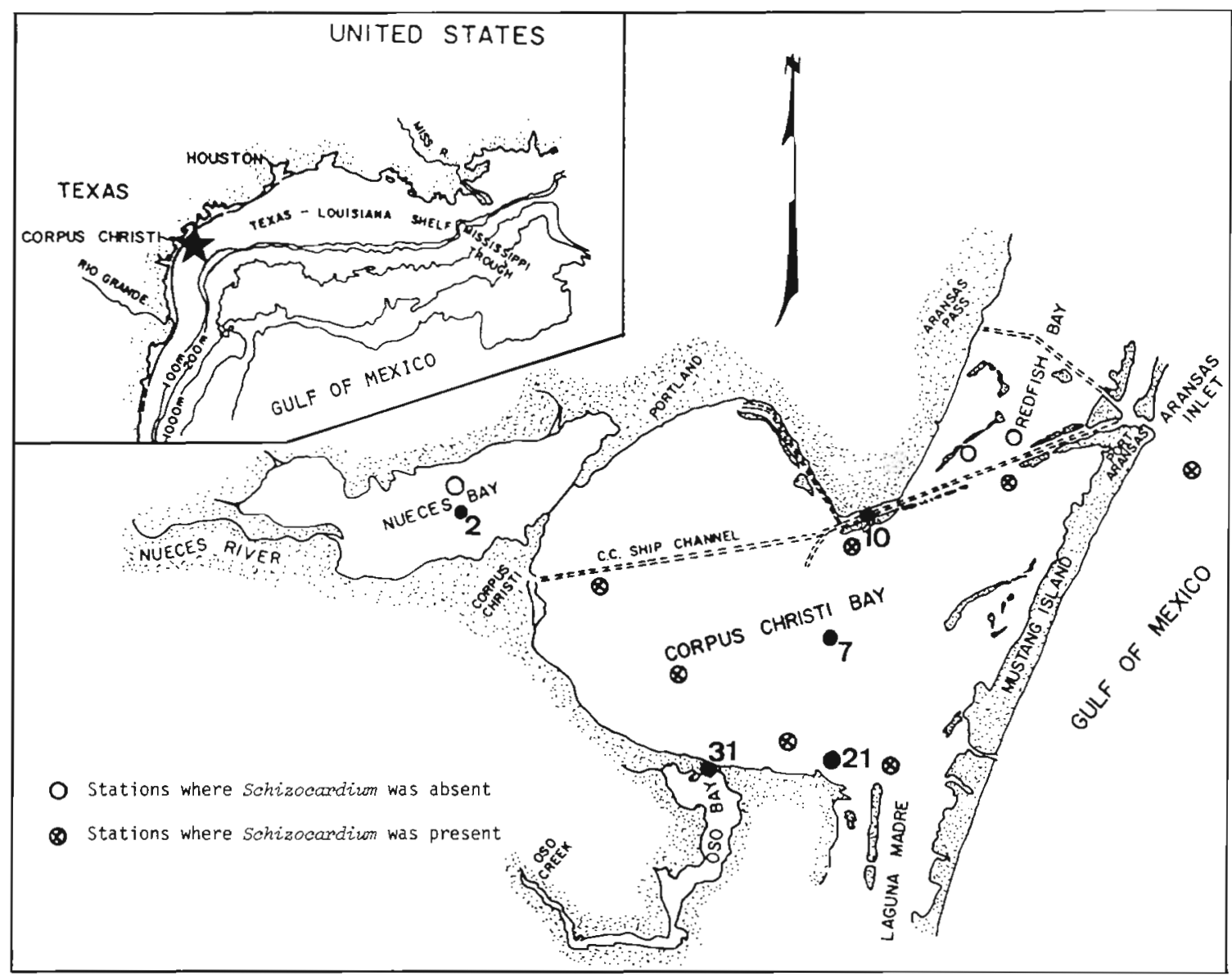

Fig. 1. Map of Corpus Christi Bay showing all benthic sampling sites where data were collected for the present study (O). Data from $\operatorname{Stn} 7$, the middle estuary site, are the focus of this study. Open $(O)$ and crossed $(\otimes)$ circles on the map represent sample sites during a 1984 synoptic cruise to search for enteropneust populations

evaluate their impact on benthic community organization.

\section{METHODS}

Sampling sites in the Corpus Christi Bay estuary are illustrated in Fig. 1. Because of interesting long-term changes in benthic community structure and availability of historical benthic community characterization at Stn 7 (Holland et al. 1975), data from this sampling site are emphasized. Stn 7 has a water depth of $4.2 \mathrm{~m}$ and is characterized by sediments comprised of muddy clays. This collection site is representative of more than $60 \%$ of the estuary's bottom habitat. The sampling intervals for which data from Stn 7 are reported included: July and October 1981; January, April, July, and October 1982; January, April, July, October, and November 1983; September and October 1984. Comparative benthic data from the other sites (Fig. 1) will be cited when necessary to illustrate specific points. More detailed descriptions of benthic communities at these other sites can be obtained from Flint \& Younk (1983) and Flint \& Kalke (1985).

All sediment sampling at $\operatorname{Stn} 7$ was accomplished using SCUBA. During each sampling interval triplicate $7.5 \mathrm{~cm}$ diameter, $30 \mathrm{~cm}$ long sediment cores were taken. The cores were capped and brought on board ship. After a minimum of $1 \mathrm{~h}$ for sediment stabilization in the cores, vertical Eh profiles were measured every $10 \mathrm{~mm}$ through each core using a Radiometer $\mathrm{pH} / \mathrm{Eh}$ Meter with a platinum/calomel electrode system. The Eh measurements were made to determine the depth of the sediment redox potential discontinuity (RPD) layer (millivolt reading equals zero). This depth was determined through linear interpolation. As described by Rhoads \& Boyer (1982), it is believed that the RPD indicates the deepest extent of oxygenated sediments and is thought to be influenced by infaunal bioturbation (McCall 1977, Rhoads et al. 1978).

The walls of each sediment core tube were split to aid in sectioning the sediments. Since most infauna are usually observed in the top $3 \mathrm{~cm}$ of Corpus Christi Bay 
sediments and the sediments of this estuary usually turn anaerobic at depths greater than $3 \mathrm{~cm}$ (Flint et al. 1982), the cores were sectioned into the following depth strata: 0 to 3,3 to 10 , and 10 to $20 \mathrm{~cm}$ sediment depth. Each stratum was placed in a $1 \mathrm{l} \mathrm{jar}$ and preserved with $10 \%$ seawater formalin containing Rose Bengal (Flint \& Holland 1980). In the laboratory, each sediment section was sieved through $0.5 \mathrm{~mm}$ mesh and the retained benthic macroinfauna identified and counted. Wet weight biomass was measured individually on the dominant macroinfaunal species and on the entire sample.

During each sampling interval additional sediment cores were obtained for water content and grain size distribution and for determination of sediment organic carbon. Sediment texture parameters were determined according to methods described by Flint \& Younk (1983). Percent total organic carbon was measured using a high temperature combustion technique, after acidification, according to methods of Hedges \& Parker (1976). During each sampling interval temperature, salinity, and $\mathrm{pH}$ (Hydrolab Surveyor 6) were measured along with bottom water dissolved oxygen (YSI Model 57 Oxygen Meter) to characterize temporal variability for the habitat. Statistical analysis methods including analysis of variance and Pearson correlation, as described in Sokal \& Rohlf (1969), were used to detect differences in temporal and spatial trends and to investigate for interrelations between species and abiotic factors. Transformation of benthos data did not significantly improve the results of these analyses so raw data were used in all cases for statistical analysis.

\section{RESULTS}

The hydrology of the middle estuary area during the study interval exhibited seasonal temperature fluctua- tions between 12 and $30^{\circ} \mathrm{C}$. Salinities ranged from 23 to $37 \mathrm{ppt}$ but were above $27 \mathrm{ppt}$ for much of the study interval. Dissolved oxygen of the bottom waters was never observed below $4.2 \mathrm{mg} \mathrm{l}^{-1}$ and usually occurred above $6.0 \mathrm{mg} \mathrm{l}^{-1}$. Water column stratification was never observed.

Average sediments in the middle estuary (Stn 7) were characterized by $76 \%$ clay, $21 \%$ silt, and $2 \%$ sand. Sediment water content (to depth of $6 \mathrm{~cm}$ ) was extremely high with values ranging from 57 to $73 \%$ (Fig. 2), and during most observations was greater than $65 \%$. From April through July 1982, sediment water dropped below $60 \%$, which was significantly lower $(\mathrm{P}<0.05)$ than other periods according to analysis of variance. Sediment organic carbon was often greater than $1 \%$ by weight (Fig. 2). Initially, in 1982, surface sediments contained greater amounts of organic carbon than deeper sediments. This pattern was reversed later in the study period, and by January 1983 the deeper sediments contained more organic carbon than the surface sediments. In contrast, other benthic sites in the estuary almost always illustrated the vertical distribution for sediment organic carbon shown by the early 1982 samples at Stn 7 (Flint \& Kalke 1985).

The most variable characteristic was the depth of the RPD (Fig. 2). From July 1981 through January 1982 an RPD depth of 1.5 to $3.2 \mathrm{~cm}$ was similar to other benthic study sites in the estuary (Flint \& Kalke 1985). After January 1982 the RPD migrated deeper in the sediments and by April 1983 had reached a maximum of $10 \mathrm{~cm}$ depth. With the shallower RPD early in the study, a blackened anaerobic (sulfur) zone was associated with the measured zero mv Eh readings. As the RPD deepened this blackened layer was no longer observed at 2 to $3 \mathrm{~cm}$ depth but occurred much deeper in the sediments. After maximum migration of the RPD to $10 \mathrm{~cm}$ sediment depth in April 1983, it returned to shallower sediments in July 1983 and remained
Fig. 2. Sediment water content (a) as \% total sediment weight, sediment redox potential discontinuity (RPD) depth (๑) in $\mathrm{cm}$, and sediment organic carbon content (bars) as \% total sediment weight for Stn 7 from 1981 to 84 . Organic carbon was measured at 3 different sediment depths (see scale)

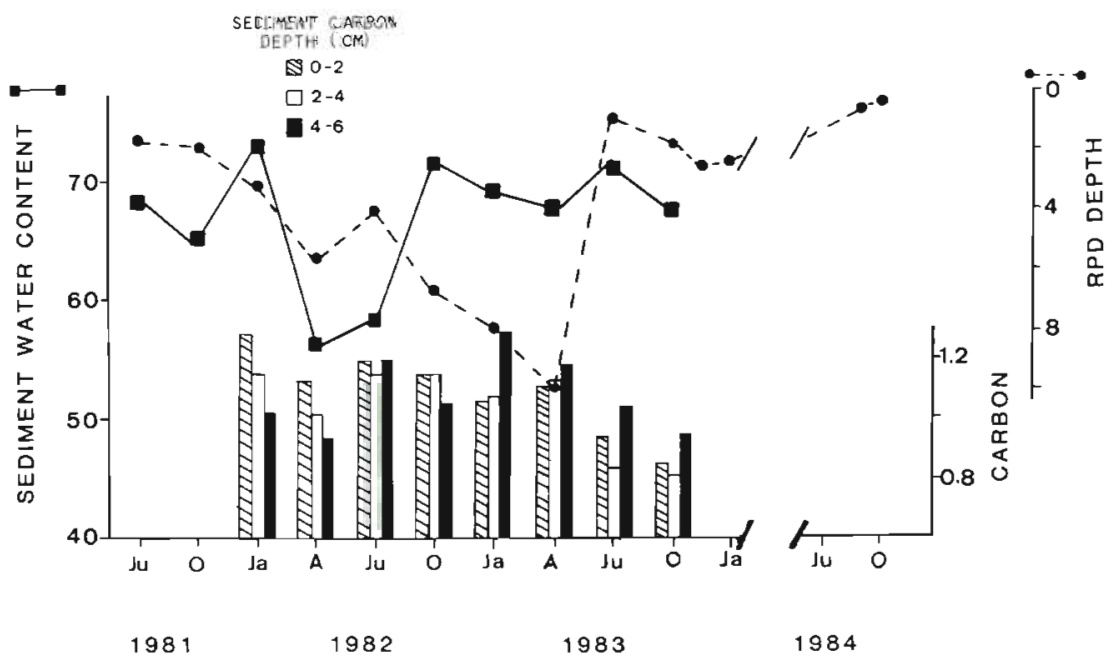


between 0.5 and $2.8 \mathrm{~cm}$ deep for the rest of the study period (Fig. 2). Although a shallower RPD was measured late in the study, the characteristic black layer was not observed, as had been the case earlier, until the final 2 sample intervals, September and October 1984. In addition, deep burrows in the cores between July and November 1983 always had an extensive area of light-brown sediments surrounding their external walls, indicative of oxygenated sediments in the immediate vicinity of the burrows.

The dominant macroinfauna observed at $\operatorname{Stn} 7$ consisted of polychaetes, with the exception of the enteropneust (acorn worm), Schizocardium new species (n. sp.). During the investigation the polychaetes Polydora caulleryi and Mediomastus californiensis dominated in total abundance (45 and $31 \%$ ), respectively) while Schizocardium n. sp. dominated in total biomass $(91 \%)$. Dominant species represented several different functional groups (feeding strategies) used to characterize benthic populations (Fauchald \& Jumars 1979). These groups ranged from tube builders to burrowers and from surface suspension-feeders to subsurface deposit-feeders.

Total macroinfaunal density and biomass were low and mostly confined to the shallower sediments during the first 3 observation periods at the middle estuary site (Fig. 3). Total infauna species richness did not exceed 6 taxa during this interval. Up until January 1982 the RPD depth accurred between 2 and $3 \mathrm{~cm}$ sediment depth. By April 1982, the extent of infaunal habitation had increased to at least $20 \mathrm{~cm}$ depth with an associated increase in depth of the RPD. Corresponding with these changes was the colonization of the enteropneust Schizocardium n. sp. at the study site. After April 1982 both macroinfaunal density and biomass continued to extend deeper into the sediments and species richness exhibited corresponding increases (Fig. 3). Peak biomass was usually observed at depth in the sediment during 1983 and early 1984. and on most occasions peak densities were usually noted at greater than $3 \mathrm{~cm}$ sediment depth. Between April 1982 and April 1983, when infaunal peak densities and biomass were at depths greater than $3 \mathrm{~cm}$, the RPD continued to migrate deeper into the sediments (Fig. 3). The collection periods of September and October 1984 revealed that both density and biomass of the community had decreased at the middle estuary site and species richness had also shown a decline. These changes corresponded to the disappearance of the enteropneust population, which occurred during the first half of 1984 . Species richness, community biomass, and community density all exhibited significant increases $(P<0.05)$ after the enteropneust was first observed at the middle estuary site, and these variables all showed significant decreases after the enteropneust's disappearance in 1984.

The macroinfaunal community at $\operatorname{Stn} 7$ was comprised exclusively of spionid polychaetes during the 1981 sampling intervals (Fig. 4) and the most abundant were Paraprionospio pinnata and Streblospio benedicti. Following a decline in these populations after October 1981, the capitellid polychaete Mediomastus californiensis appeared in samples and steadily increased in density. In April 1982 the enteropneust Schizocardium n.sp. occurred in extremely high densities. These initial colonizers were small-sized, with low population biomass (Fig. 4), and were likely the result of a massive settlement of this species in the area, since none had been observed previously (e.g. Holland et al. 1975). The Schizocardium population

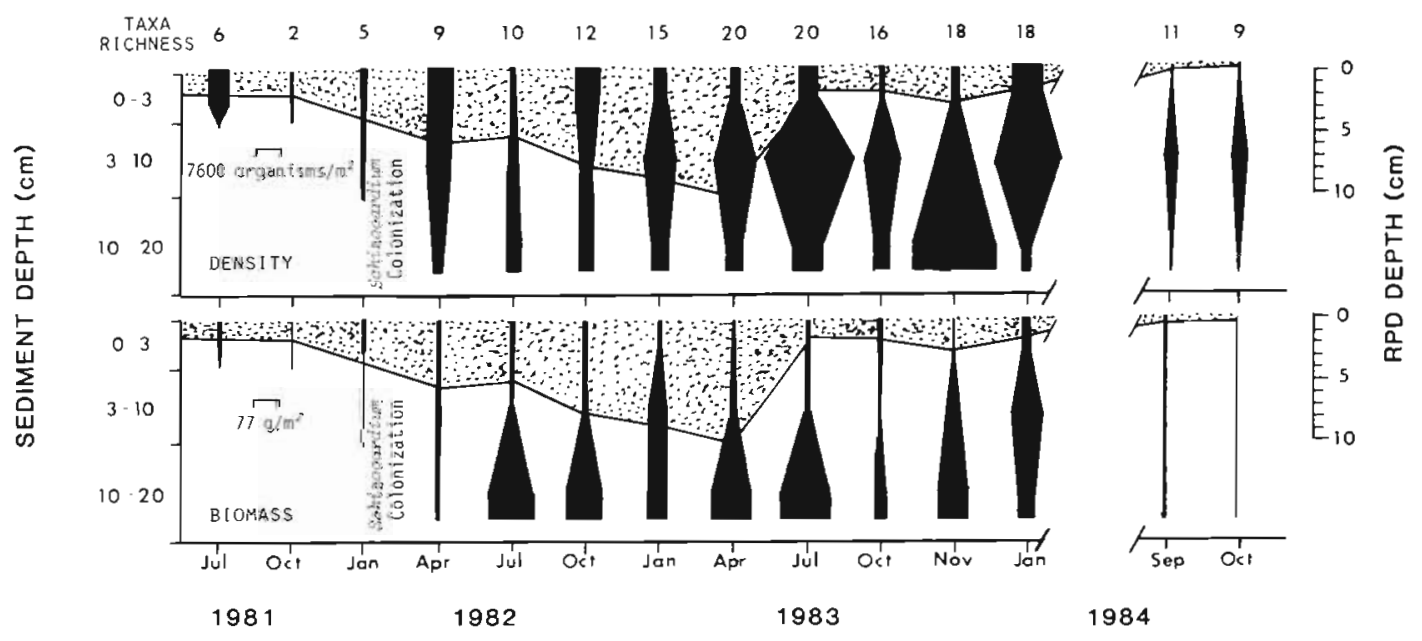

Fig. 3. Vertical distribution of benthic macroinfaunal community density and biomass at Stn 7 in Corpus Christi Bay for 14 sampling intervals during 1981 to 84 . Total taxa richness is listed above each plot and the depth of the RPD layer is indicated by the lower border of stippling 
Fig. 4. Mean density of the dominant species observed at $\operatorname{Stn} 7$ in Corpus Christi Bay during the 1981 to 84 sampling period. Note that for Schizocardium n. sp. both density and biomass plots are shown and biomass is according to the same scale (axis) as density. Although measured standard deviations are not shown for sake of figure clarity, coefficients of variation for any of the mean mea-

sures never exceeded $14.5 \%$

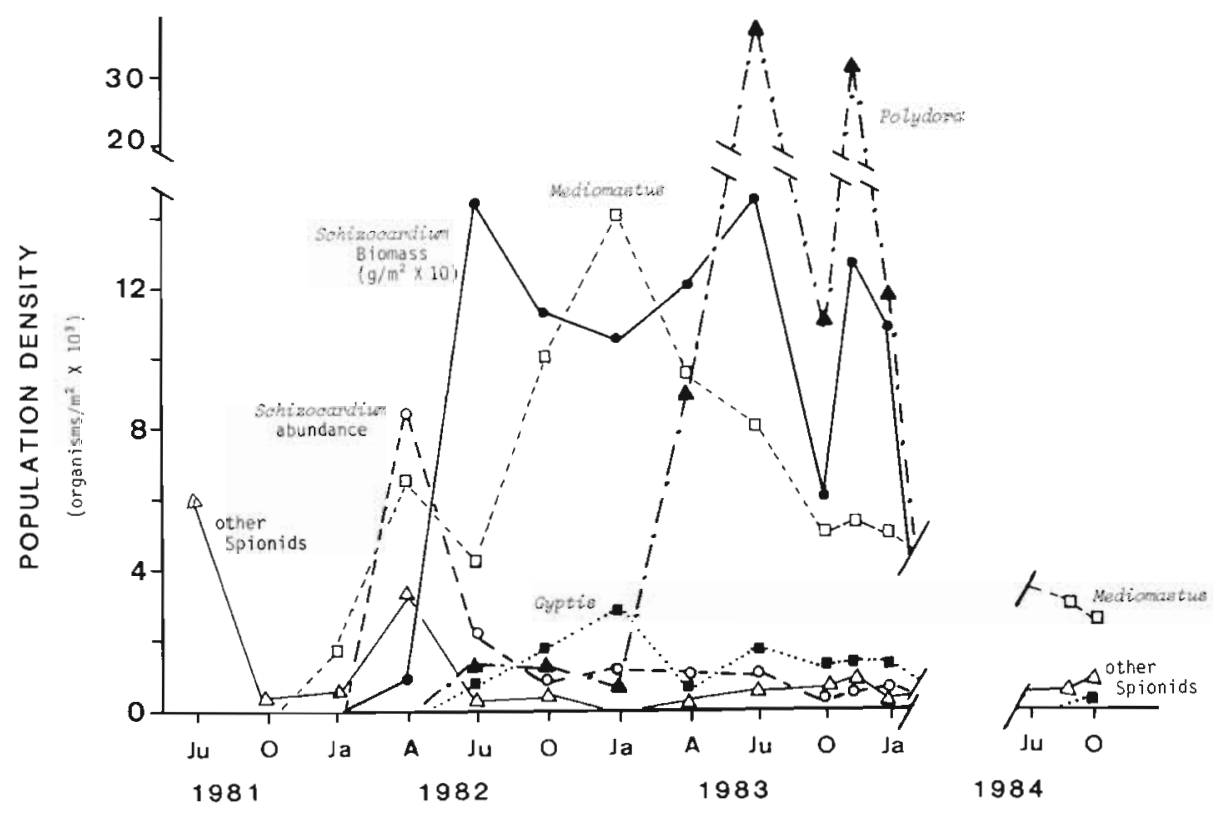

grew rapidly and by July 1982, population biomass was very large and remained so throughout January 1984. From late 1982 through January 1984 adult enteropneusts greater than $5 \mathrm{~cm}$ total body length comprised the majority of the population and juveniles less than $2 \mathrm{~cm}$ were not observed. We compared biomass of the enteropneust to other species densities because we felt that the large size of this organism would cause its standing crop to have more of an effect on the other taxa densities than its actual numbers, which were often low. Between January and September 1984 the enteropneust population disappeared from the middle estuary site and all other populations also declined (Fig. 4)

The large increase in biomass of the Schizocardium n. sp. population in July 1982 paralleled a drop in Mediomastus californiensis and spionid densities (Fig. 4). With a decrease in Schizocardium standing crop after this sampling interval, $M$. californiensis densities again increased whereas the spionid densities (Paraprionospio pinnata and Streblospio benedicti) did not. In January 1983 M. californiensis reached its maximum population densities. Sediment colonization by Schizocardium n. sp. paralleled an increased taxa richness at Stn 7 (Fig. 3) which included the polychaetes Gyptis vittata and Polydora caulleryi in July 1982. In July 1983 P. caulleryi became the dominant infaunal species at the site (Fig. 4). As $P$. caulleryi populations became more dense, $M$. californiensis as well as other polychaete populations began to decline (Fig. 5).

The vertical pattern of dominant populations illustrated specific faunal distributions in the $\operatorname{Stn} 7$ softbottom community (Fig. 5). Tube building, surface deposit-feeding spionids, such as Paraprionospio pinnata, inhabited the sediments early in the investigation and confined their populations to the upper $3 \mathrm{~cm}$.

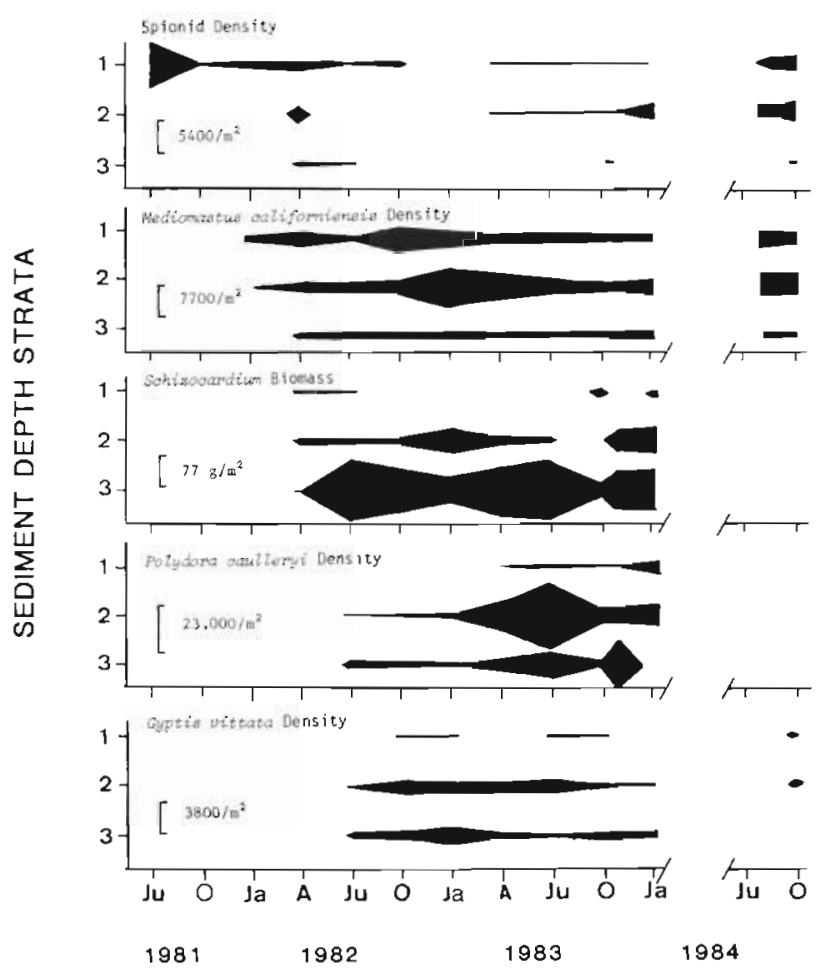

Fig. 5. Vertical and temporal distributions of the dominant taxa observed at the Corpus Christi Bay middle estuary sampling site during the 1981 to 84 study period. All distributions represent species mean density except for Schizocardium n. sp., where mean biomass is shown instead. The sediment depth strata are as follows: 0 to $3 \mathrm{~cm}$ equals $1 ; 3$ to $10 \mathrm{~cm}$ equals $2 ;$ and 10 to $20 \mathrm{~cm}$ equals 3 
Mediomastus californiensis, a burrowing depositfeeder, was observed in January 1982 samples and occurred to $10 \mathrm{~cm}$ sediment depth. With the occurrence of Schizocardium n. sp. throughout the sediments in April 1982, both the spionid polychaete populations and $M$. californiensis extended their ranges into deeper sediments and the spionids exhibited increased densities over the previous 2 sampling intervals (Fig. 5). Following establishment of enteropneust biomass concentrations in deeper sediments, the burrowing, subsurface deposit-feeding polychaete, Gyptis vittata and the tubiculous polychaete Polydora caulleryi colonized the study site sediments and distributed themselves throughout the first $20 \mathrm{~cm}$. P. caulleryi was not observed until 1983 and when peak densities for this population occurred, they were always observed in the deeper sediment strata, which was thought unusual for a tubiculous, surface depositfeeder. The taxa discussed above continued to inhabit the site and maintained their vertical range over a considerable sediment depth through January 1984. In several $1 \mathrm{~m}$ long cores macroinfauna were never observed deeper than $20 \mathrm{~cm}$ in the sediments, although Schizocardium n. sp. tubes were noted the full extent of the cores. Between January and September 1984 spionids increased their densities to $10 \mathrm{~cm}$ sediment depth. Schizocardium and $P$. caulleryi populations disappeared from the site and $G$. vittata populations declined and were confined to depths less than $10 \mathrm{~cm}$ (Fig. 5).

\section{DISCUSSION}

We believe that the changes in soft-bottom benthic community structure observed during this investigation were directly attributed to the colonization of an enteropneust population that was first observed in April 1982. In the spring of 1984 a synoptic sampling cruise was conducted in the Corpus Christi Bay estuary to determine if the occurrence of the enteropneust at Stn 7 was an isolated event. All of the areas represented by a circle in Fig. 1 were sampled for benthic invertebrates. As shown by the circles containing an $\mathrm{X}$. a good part of the estuary supported Schizocardium populations, indicating that Stn 7 was not unique in this respect.

Total macroinfaunal species richness increased from an average of 4 prior to April 1982 to an average of 15 after April 1982 at Stn 7. Number of taxa declined again in September 1984, after the enteropneust population had disappeared from the site. In contrast, benthic collections taken monthly between October 1972 and May 1975 at the same site (Holland et al. 1975) showed a 3 yr average of 10 taxa inhabiting these sediments and total infaunal density during this study averaged 1038 ind $\mathrm{m}^{-2}$. In the present investigation, total macroinfaunal density prior to April 1982 averaged 2974 ind $\mathrm{m}^{-2}$, whereas after April 1982 average total density was 19039 ind $\mathrm{m}^{-2}$. After disappearance of the enteropneust population, between January and September 1984, average density declined to 4089 ind $\mathrm{m}^{-2}$. In addition, historical records on this site (1972-75) indicated that Paraprionospio pinnata, Mediomastus californiensis and the small depositfeeding polychaete Cossura delta were the dominant populations during earlier years. Schizocardium n. sp. and Polydora caulleryi were never observed during the earlier 3 yr study. We concluded therefore, that the community structure changes between April 1982 and January 1984 deviated from long-term patterns at this middle estuary site and probably other sites in the estuary supporting enteropneust populations.

In contrast to Stn 7 , vertical distributions of the macroinfaunal community at other benthic sites in the estuary between 1981 and 1984 not supporting enteropneusts did not show similar patterns. For example, the vertical and temporal distributions of total density at Stns 2 and 10 (Fig. 1) showed peak densities in the surface sediments, to approximately $3 \mathrm{~cm}$ depth (Fig. 6). On numerous occasions fauna were not even present in sediments deeper than $10 \mathrm{~cm}$. At both of these sites the RPD never exceeded $4 \mathrm{~cm}$ depth and usually occurred at less than $3 \mathrm{~cm}$. Patterns of total community biomass at these other benthic sites followed similar trends as those observed for density (Flint \& Kalke 1985)

We suggest that benthic community organization at Stn 7 was the result of interactions between dominant taxa of the community mediated by the natural disturbance effects of the enteropneust on the community.

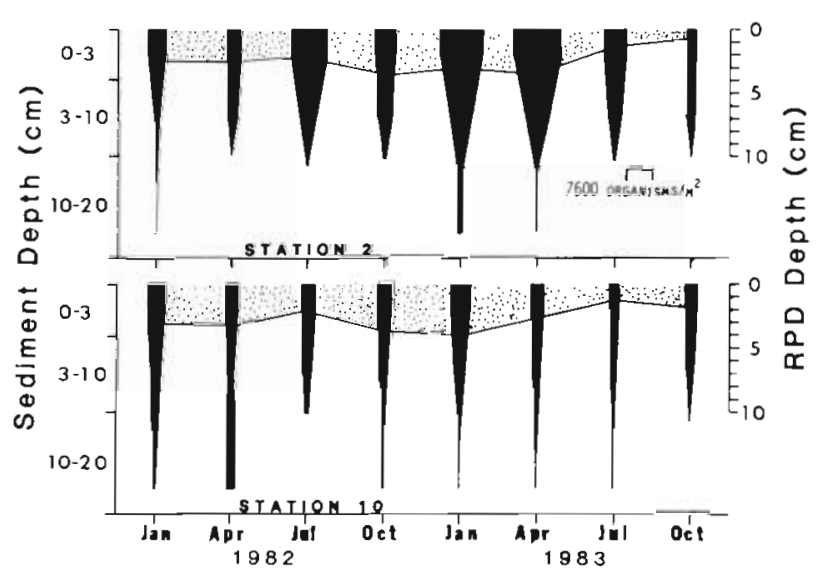

Fig. 6. Vertical distribution of the benthic macroinfaunal community density at Stns 2 and 10 (see Fig. 1) in Corpus Christi Bay. Depth of RPD layer is indicated by lower border of stippling 
Table 1. Two-way analysis of variance results for the investigation of differences in the factors of time and sediment depth strata on the dominant taxa distributions in the benthic community of Corpus Christi Bay. Probability levels for each comparison are shown along with the interaction effects between factors. Degrees of freedom for each factor are also given

\begin{tabular}{|lccc|}
\hline Taxon & Time & $\begin{array}{c}\text { Depth } \\
\text { strata } \\
\text { (df: 2) }\end{array}$ & $\begin{array}{c}\text { Inter- } \\
\text { actions } \\
\text { (df: 20) }\end{array}$ \\
\hline Spionids & & & \\
Mediomastus californiensis & 0.001 & 0.001 & 0.001 \\
Schizocardium n. sp. & 0.001 & 0.001 & 0.001 \\
Gyptis vittata & 0.009 & 0.216 & 0.005 \\
Polydora caulleryi & 0.001 & 0.001 & 0.005 \\
& & & 0.010 \\
\hline
\end{tabular}

Differences in distribution of the dominant fauna occurred from October 1981 to October 1984 (Fig. 4 \& $5)$. Analysis of variance (2-way on factors of time and sediment depth) indicated that temporal differences in taxa distribution were significant (Table 1). Either (1) seasonal environmental characteristics exerted an effect on densities (e.g. reproductive cycles) or (2) species interactions occurred that caused temporal changes in distribution. Significant differences in sediment vertical distribution for all taxa, except Schizocardium n. sp., also were noted (Table 1). Peak densities of each taxa occurred at specific depths in the sediment column (also seen in Fig. 5). For example, spionids, with the exception of Polydora caulleryi, occurred in the 0 to $3 \mathrm{~cm}$ depth range while peak Mediomastus californiensis densities occurred in sediments to $10 \mathrm{~cm}$ depth. P. caulleryi and Gyptis vittata peak densities were usually observed below $3 \mathrm{~cm}$ depth. Interactions between the factors of time and sediment depth were also noted (Table 1) and were the result of vertical changes in peak distributions of the different taxa over the study period (Fig. 5).

Species interactions were suggested above as one potential factor influencing the significant differences observed in temporal distributions of dominant taxa. Changes in the RPD layer (depth of oxygenated sediments) during this investigation (Fig. 2) also appeared to parallel patterns in some of these dominant infauna. Correlations found to be significant between specific taxa distributions and between taxa and the depth of the RPD included the following. There was a positive correlation between depth of the RPD and both Mediomastus californiensis density (0.70) and Schizocardium n. sp. biomass (0.68). There was a negative correlation between depth of the RPD and Polydora caulleryi density $(-0.65)$. Schizocardium n. sp. standing crop was negatively correlated with Paraprionospio pinnata density $(-0.81)$ and positively correlated with $M$. californiensis density (0.64). P. caulleryi distributions were negatively correlated with both $P$. pinnata $(-0.45)$ and $M$. Californiensis densities $(-0.66)$. M. californiensis and Gyptis vittata, both burrowing, deposit-feeders, were strongly correlated with one another in their distributions $(0.87)$.

Other benthic study sites in Corpus Christi Bay supported several of the dominant fauna observed at $\operatorname{Stn} 7$ after April 1982 (Flint \& Kalke 1985). Where Mediomastus californiensis and Polydora caulleryi occurred together at other sites, a correlation of $\mathrm{r}=$ $-0.56(n=25)$ on densities between the 2 species was measured, indicating that the 2 taxa did not normally occur in high densities together. $\operatorname{Stn} 7$ dominant infaunal species collected from other benthic study sites not supporting populations of Schizocardium usually occurred in greatest density in shallower sediments. For example, Table 2 illustrates 3 of the Stn 7 dominant polychaetes and their distribution at other benthic sites. Average depth of the RPD layer was shallower and all 3 species limited their peak distributions to less than $10 \mathrm{~cm}$ sediment depth. It would appear that these populations were distributed differently in sediments devoid of Schizocardium n. sp. compared to when it was present in the community (e.g. Fig. 5).

A similar pattern was observed when burrowing ophiuroids occurred in sediments. For example, Fig. 7 shows benthic infaunal distribution for 3 similar sediment cores taken in close proximity to one another in Corpus Christi Bay. Two cores exhibited vertical dis-

Table 2. Mean and standard error of benthic taxa density distributions at other sampling sites in Corpus Christi Bay where the enteropneust Schizocardium n. sp. did not occur, that were also species characteristic of the St 7 benthic community. RPD depth range of these other sampling sites is also shown

\begin{tabular}{|c|c|c|c|}
\hline Species & $\begin{array}{l}\text { Sediment } \\
\text { depth } \\
\text { (cm) }\end{array}$ & $\begin{array}{c}\text { Mean density } \\
\text { (organisms } \\
0.01 \mathrm{~m}^{-2} \text { ) }\end{array}$ & $\begin{array}{l}\text { RPD } \\
\text { range } \\
\text { (cm) }\end{array}$ \\
\hline $\begin{array}{l}\text { Mediomastus } \\
\text { californiensis } \\
\qquad(n=20)^{1}\end{array}$ & $\begin{array}{r}0-3 \\
3-10 \\
10-20\end{array}$ & $\begin{array}{r}26.1 \pm 9.2 \\
33.2 \pm 8.9 \\
1.6 \pm 1.4\end{array}$ & $2-3$ \\
\hline $\begin{array}{l}\text { Gyptis vittata } \\
(\mathrm{n}=8)\end{array}$ & $\begin{array}{r}0-3 \\
3-10 \\
10-20\end{array}$ & $\begin{array}{l}2.1 \pm 1.1 \\
0.4 \pm 0.2 \\
0.5 \pm 0.3\end{array}$ & $2-4$ \\
\hline $\begin{array}{l}\text { Polydora caulleryi } \\
\qquad(\mathrm{n}=6)\end{array}$ & $\begin{array}{r}0-3 \\
3-10 \\
10-20\end{array}$ & $\begin{array}{rr}128.0 \pm 26.2 \\
16.3 \pm 5.8 \\
1.3 \pm 0.6\end{array}$ & $2-4$ \\
\hline \multicolumn{4}{|c|}{$\begin{array}{l}{ }^{1} \text { Indicates the number of samples that contained the } \\
\text { species of interest without populations of Schizocardium } \\
\text { n. sp. present }\end{array}$} \\
\hline
\end{tabular}


CORE 1

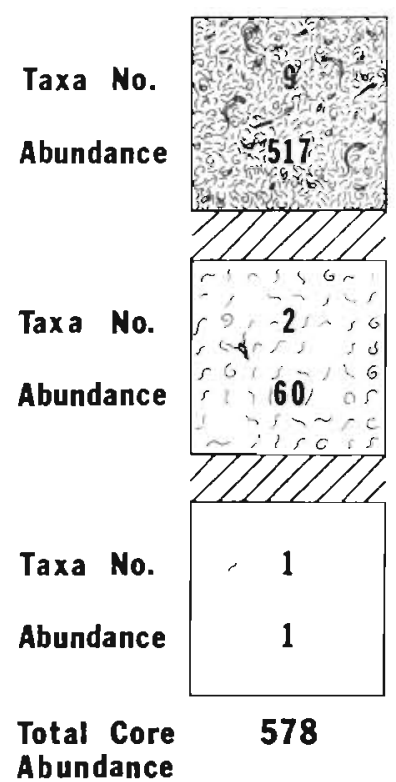

CORE 2

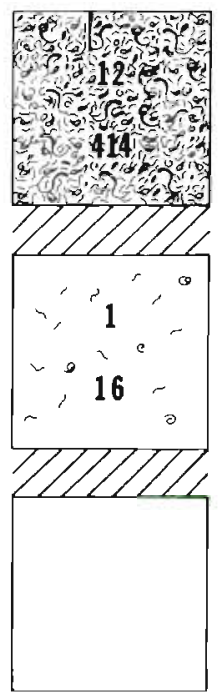

430
CORE 3

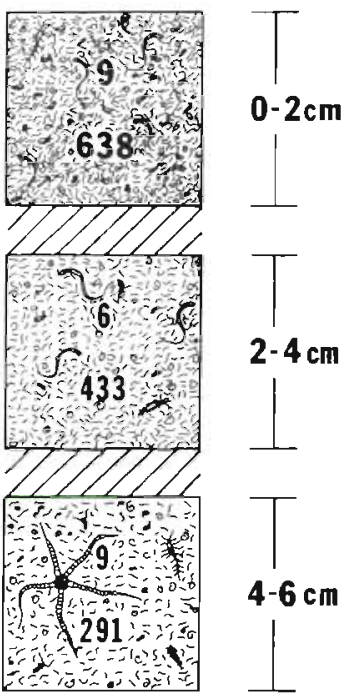

1362

Fig. 7. Vertical distribution of macroinfauna taxa from 3 cores taken simultaneously at the same sampling location in the Corpus Christi Bay estuary. A large burrowing ophiuroid was observed in the deepest section of core 3 tribution of fauna with maximum abundances and diversity in the top 1 to $2 \mathrm{~cm}$ of sediment. The range of fauna and greater abundances throughout the top $6 \mathrm{~cm}$ in the third core were correlated with the presence of an ophiuroid in the deeper sediments. We believed that natural disturbance caused by sediment reworking activities (bioturbation) of the ophiuroid (Woodley 1975) created a habitat for other infaunal populations to expand deeper into the sediments, and for the community to become more diverse.

We propose the following to explain the results observed during this study. Prior to enteropneust colonization at Stn 7 sediments were characterized by a homogeneous mud to $20 \mathrm{~cm}$, very little faunal burrowing, and a black anoxic layer at approximately $3 \mathrm{~cm}$ depth. After April 1982 the sediments were intermeshed with tubes and pockets and enteropneusts often were observed in these pockets or moving through the large burrow network in split cores. The sediments were usually light brown in color and the characteristic blackened layer was absent, suggesting that the sediments were aerobic to considerable depths (Yingst \& Rhoads 1980), as verified by the extent of the measured RPD layer (Fig. 2). Corresponding to extensive burrowing, a shift in organic carbon content of various sediment strata occurred while water content decreased initially and the RPD of these sediments shifted deeper than was observed previously (Fig. 2). The depth of the RPD layer was correlated with both increasing density of Mediomastus californiensis and increasing biomass of Schizocardium n. sp. Although this deeper movement paralleled the colonization by M. californiensis (Fig. 4), the RPD depth of $3.2 \mathrm{~cm}$ was not uncharacteristic of other benthic sites in Corpus Christi Bay where this species dominated the community (e.g. Table 2). The more dramatic shifts in RPD were associated with the greater biomasses of Schizocardium n. sp. that developed at this site in April 1982 (Fig. 5), and implicated this species' impact on the environment.

Polydora caulleryi populations usually recruited into the benthic communities of this estuary in spring (Flint et al. 1982). In April 1982 large densities of Paraprionospio pinnata $\left(3230 \mathrm{~m}^{-2}\right)$ inhabited the surface sediments of $\operatorname{Stn} 7$ along with large densities of Schizocardium n. sp. (Fig. 5). This spionid feeds on the surface sediments with wide ranging palps and has been observed to take small animals (authors unpubl. lab. obs., Dauer 1985). Although $P$. caulleryi colonized the sediments between April and July 1982 (Fig. 4) its density remained small and we believe that the high densities of $P$. pinnata as well as extensive bioturbation activities by Schizocardium during this period eliminated many of the recruiting $P$. caulleryi, as predicted by adult-larval interaction theory (Woodin 1976).

There was a strong negative correlation between Paraprionospio pinnata and Schizocardium n. sp. and by April $1983 P$. pinnata was less dense $\left(230 \mathrm{~m}^{-2}\right)$ than in 1982. Polydora caulleryi thus encountered less interference in its recruitment, and was able to establish a significantly denser population in 1983 than it did in the spring of 1982 (Fig. 5). The fact that P. pinnata was historically a dense population at this study site (e.g. Holland et al. 1975) may further serve to explain why $P$. caulleryi populations were never abundant until 
more recently, coinciding with the colonization of the enteropneust. The $P$. caulleryi population was also able to maintain high densities in the same sediment column that supported high densities of the burrowing polychaete Mediomastus californiensis (Fig. 4), contrary to observations at other sites. This co-dominance occurred because a greater extent of oxygenated sediment was able to be inhabited.

With the establishment of derise populations of the tube-building spionid Polydora caulleryi at the study site the RPD depth of the sediments began to migrate toward the surface again (Fig. 2). There was a negative correlation between RPD depth and $P$. caulleryi densities. The stabilization of sediments by the high density of $P$. caulleryi tubes, as described for other tube building polychaetes (Woodin \& Jackson 1979), could have inhibited the sediment reworking abilities and ventilating activities of dominant subsurface burrowers, causing the RPD depth to decrease. Although both populations were large, there was a negative correlation between $P$. caulleryi and Mediomastus californiensis densities, the dominant subsurface, burrowing polychaete population at this study site.

Between January and September 1984 Schizocardium populations disappeared from the benthic community at Stn 7 in Corpus Christi Bay. Possible explanations for this disappearance could include changes in sediment habitat or changes in the more general estuarine environment. As discussed above, the sediment habitat showed changes in RPD layer depth (July 1983) which were thought to be affected by a tubiculous polychaete. Sulfate reduction might have increased in the sediments at this site because of greater summer water temperatures, which would serve as an alternative explanation for a shallower anoxic layer. Migration of the RPD to 1 to $2 \mathrm{~cm}$ depth, however, was not observed in 1982. A much deeper RPD layer was evident during this period than in July 1983 (Fig. 2) suggesting dynamics were more complex than simply sulfate reduction. Sediment organic content also decreased later in the study (Fig. 2), which could have reflected a decrease in food availability for the enteropneust population. On an estuarine-wide scale, salinities in excess of $36 \mathrm{ppt}$ were observed in the summer of 1984 (Fig. 8). This abrupt change in salinity may have been sufficient to eliminate Schizocardium populations. As Fig. 8 illustrates, other periods of Schizocardium occurrence in the estuary paralleled intervals of lower salinity. On all occasions, when salinity increased the enteropneust disappeared.

Whatever the cause, the disappearance of the large enteropneust correlated with some major changes in benthic community organization. Most obvious was the re-establishment of Paraprionospio pinnata and Streblospio benedicti, and overall increase in other spionid populations (Fig. 5). Polydora caulleryi disappeared from the habitat and the diversity of the community was much less. These results identified several of the mechanisms at work in structuring benthic communities when a mobile, large-sized organism colonizes a soft-bottom habitat, such as the echiuran described by Stull \& Haydock (1982), the ophiuroid illustrated in Fig. 7, the enteropneust described by Thistle (1980), or the enteropneust discussed here. We believe that the presence of the Schizocardium n. sp. population in the soft-bottom community, with its sediment reworking abilities, limited population density of one dominant spionid ( $P$. pinnata) and created a larger vertical extent to the otherwise confined aerobic conditions in these sediments, allowing other populations to extend into deeper than normal sediments. Numerous studies of soft-bottom communities have implicated competition for space as one organizing force acting on community structure (e.g. Levinton 1977, Woodin 1978, Heck \& Orth 1980, Peterson \& Andre 1980, Woodin 1981). Differences in vertical space utilization apparently are an effective mechanism for reducing interspecific competition in soft-bottom communities
Fig. 8. Eleven yr record of surface salinity in the Corpus Christi Bay estuary. Periods of occurrence for the enteropneust Schizocardium n. sp. are indicated along with total number of individuals collected

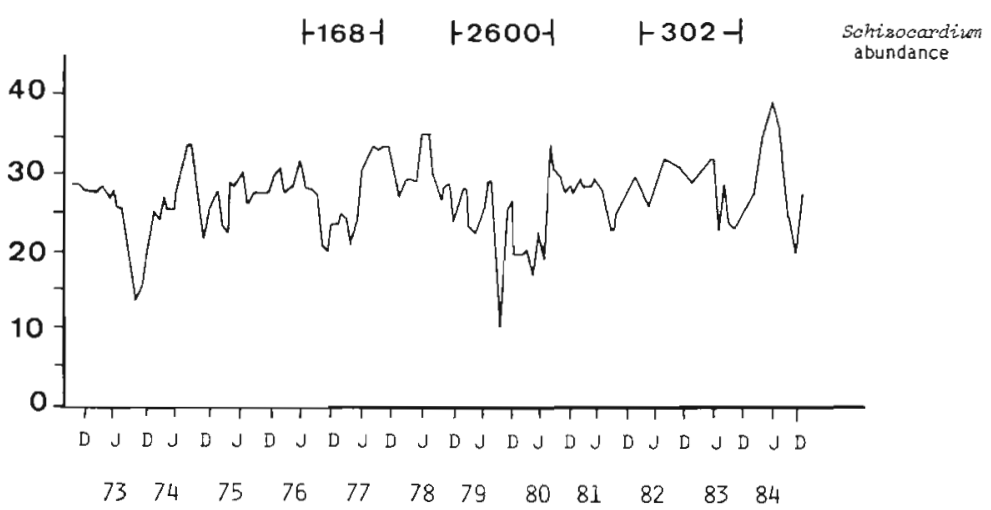

MONTH and YEAR 
(Peterson 1979, Whitlatch 1980, Wilson 1981). The disappearance of the enteropneust and associated biological effects during our study resulted in community organization that approached pre-enteropneust colonization characteristics, further confirming the effect of this species on community organization.

Acknowledgements. Funding for this research was provided in part by the Texas Department of Water Resources (Contract \pm IAC 82-83 1900) and the Texas A \& M College Sea Grant Program (Grant \pm NA81AA-D-0092). Thanks are extended to our colleagues M. McCoid and S. Rabalais who spent time in collecting samples and working up data over the years. Further thanks are given to Dr. K. Woodwick of California State Univ., Fresno, for help with the taxonomy of the enteropneust, Schizocardium new species. Appreciation is also extended to $M$. Valentino for manuscript preparation. This manuscript is contribution No. 672 of the University of Texas Marine Science Institute and State University of New York Research Center at Oswego Contribution No. 28

\section{LITERATURE CITED}

Connell, J. H. (1975). Some mechanisms producing structure in natural communities: a model and evidence from field experiments. In: Cody, M. L., Diamond, J. (ed.) Ecology and evolution of communities. Belknap Press, Cambridge, p. $460-490$

Coull, B. C., Palmer, M. A. (1984). Field experimentation in meiofaunal ecology. Hydrobiologia 18: 1-19

Creed, E. L., Coull, B. C. (1984). Sand dollar, Mellita quinquiesperforata, and sea pansy, Renilla reniformis, effects on meiofaunal abundance. J. exp. mar. Biol. Ecol. 84: 225-234

Dauer, D. M. (1985). Functional morphology and feeding behavior of Paraprionospio pinnata (Polychaeta: Spionidae). Mar. Biol. 85: 143-152

Fauchald, K., Jumars, P. (1979). The diet of worms: a stucty of polychaete feeding guilds. Oceanogr. mar Biol. A. Rev. 17: $193-284$

Flint, R.W. (1985). Long-term estuarine variabılity and associated biological response. Estuaries 8: 158-169

Flint, R. W., Holland, J. S. (1980). Benthic infaunal variability on a transect in the Gulf of Mexico. Estuar. coast. mar. Sci. 10: $1-14$

Flint, R. W., Rabalais, S., Kalke, R. D. (1982). Estuarine benthos and ecosystem functioning. In: Davis, J. R. (ed.) Proc. Symp. Recent Benthological Findings in Texas and Adjacent States. Texas Acad. Sci., Austin, p. 185-201

Flint, R. W., Younk, J. A. (1983). Estuarine benthos: long-term community structure variations, Corpus Christi Bay, Texas. Estuaries 6(2): 126-141

Flint, R. W., Kalke, R. D. (1985). Benthos structure and function in a south Texas estuary. Contr. Mar Sci. 28: 33-53

Heck, K. L., Orth, R. J. (1980). Seagrass habitats: the roles of habitat complexity, competition and predation in structuring associated fish and motile macroinvertebrate assemblages. In: Kennedy, V.S. (ed.) Estuarine perspectives. Academic Press, New York, p. 449-464

Hedges, I., Parker, P. L. (1976). Land-derived organic matter in surface sediments from the Gulf of Mexico. Geochim. cosmochim. Acta 40: 1019-1029
Holland, J. S., Maciolek, N. J., Kalke, R. D., Mullins, L., Oppenheimer, C. H. (1975). A benthos and plankton study of the Corpus Christi, Copano, and Aransas Bay systems. Final Rpt. to Texas Water Development Board from the Univ. Texas Marine Science Inst., Austin, p. 1-174

Levinton, J. S. (1977). Ecology of shallow water deposit-feeding communities in Aquisset Harbor, Massachusetts. In: Coull, B. C. (ed.) Ecology of marine benthos. Univ. South Carolina Press, Columbia, p. 191-227

Lewin, R. (1983). Predators and hurricanes change ecology. Science 221: 737-740

MacArthur, R. H., Levins, R. (1967). The limiting similarity, convergence, and divergence of coexisting species. Am. Nat. 101: 377-385

McCall, P. L. (1977). Community patterns and adaptive strategies of the infaunal benthos of Long Island Sound. J. mar. Res. 35: 221-266

Paine, R.T. (1969). The Pisaster-Tegula interaction: prey patches, predator food preference, and intertidal community structure. Ecology 50: 950-961

Paine, R. T. (1980). Food webs: linkage, interaction strength, and community infrastructure. J. Anim. Ecol. 49: 667-685

Peterson, C. H. (1979). Predation, competitive exclusion, and diversity in the soft-sediment benthic communities of estuaries and lagoons. In: Livingston, R. J. (ed.) Ecological processes in coastal and marine systems. Plenum Press, New York, p. 233-264

Peterson, C. H., Andre, S. V (1980). An experimental analysis of interspecific competition among marine filter feeders in a soft-sediment environment. Ecology 61: 129-139

Rhoads, D. C., McCall, P. L., Yingst, J. Y (1978). Disturbance and production on the estuarine seafloor. Am. Scient. 66: $577-586$

Rhoads, D. C., Boyer, L. F. (1982). The effects of marine benthos on physical properties of sediments: a successional perspective. In: McCall, P. L., Tevesz, M. J. S. (ed.) Animal-sediment relations, the biogenic alteration of sediments. Plenum Press, New York, p. 3-52

Sokal, R. R., Rohlf, F. J. (1969). Biometry, the principles and practice of statistics in biological research. W. H. Freeman and Co., San Francisco

Stull, J. K., Haydock, C. I. (1982). Effects of bioturbation by Listrolobus pelodes on coastal shelf sediments modified by a major California wastewater discharge (Abstract). EOS (Trans. Am. geophys. Un.) 63(3): 105

Thistle, D. (1980). The response of a harpacticoid copepod community to a small-scale natural disturbance. J. mar Res. 38: 381-395

Virnstein, R. W. (1979). Predation on estuarine infauna: response patterns of component species. Estuaries 2(2): $69-86$

Whitlatch, R. B. (1980). Pattems of resource utilization and coexistence in marine intertidal deposit-feeding communities. J. mar. Res. 38: 743-765

Wilson, W. H. (1981). Sediment-mediated interactions in a densely populated infaunal assemblage: the effects of the polychaete Abarenicola pacifica. J. mar. Res. 39: 735-748

Woodin, S. A. (1976). Adult-larval interactions in dense infaunal assemblages: patterns of abundance. J. mar. Res. 34: $25-41$

Woodin, S. A. (1978). Refuges, disturbance, and community structure: a marine soft-bottom example. Ecology 59: $274-284$

Woodin, S. A. (1981). Disturbance and community structure in a shallow water sand flat. Ecology 62: 1052-1066

Woodin, S. A., Jackson, J. B. C. (1979). Interphyletic competition among marine benthos. Am. Zool. 19: 1029-1043 
Woodley, J. D. (1975). The behavior of some amphiurid brittle-stars. J. exp. mar. Biol. Ecol. 18: 29-46

Yingst, J. Y., Rhoads, D. C. (1980). The role of bioturbation in the enhancement of bacterial growth rates in marine sediments. In: Tenore, K. R., Coull, B. C. (ed.) Marine benthic dynamics. Univ. South Carolina Press, Columbia, p. $407-421$

Zajac, R. N., Whitlatch, R. B. (1982). Responses of estuarine infauna to disturbance. I. Spatial and temporal variation of initial recolonization. Mar Ecol. Prog. Ser. 10: 1-14

This article was submitted to the editor; it was accepted for printing on February 7,1986 